\title{
Prevalence and Characterization of Aeromonas Spp. Isolated from Some Meat Products in Egypt
}

\author{
Zakaria Hassan Elbayoumi ${ }^{1, *}$, Rasha Nabil Zahran ${ }^{2}$, and Reyad R Shawish ${ }^{1}$ \\ ${ }^{1}$ Department of Food Hygiene \& Control, Faculty of Veterinary Medicine, University of Sadat City, Egypt \\ ${ }^{2}$ Department of Bacteriology, Mycology and Immunology, Faculty of Veterinary Medicine, University of Sadat City, Egypt
}

*Corresponding author: Dr. Zakaria Hassan Elbayoumi, Department of Food Hygiene \& Control, Faculty of Veterinary Medicine, University of Sadat City, Egypt, Tel: +201000710442; E-mail: zico76us@yahoo.com

Received: 08 Mar, 2021 | Accepted: 31 Mar, 2021 | Published: 16 Apr, 2021

Citation: Elbayoumi ZH, Zahran RN, Shawish RR (2021) Prevalence and Characterization of Aeromonas Spp. Isolated from Some Meat Products in Egypt. Nutr Food Technol Open Access 7(1): dx.doi.org/10.16966/2470-6086.170

Copyright: (c) 2021 Elbayoumi ZH, et al. This is an open-access article distributed under the terms of the Creative Commons Attribution License, which permits unrestricted use, distribution, and reproduction in any medium, provided the original author and source are credited.

\begin{abstract}
Background/Objective: Meat products are one of the most valuable foods for human consumption. However, meat products may also act as a source of food borne pathogens including Aeromonas species which caused a serious threat to a public health concern. This study aimed to investigate the prevalence and virulence characteristics of Aeromonas species isolated from meat products in Egypt.

Methods: A total of 180 random samples of meat products represented by minced meat, beef burger, kofta and sausage ( 45 of each) collected from different shops and supermarkets at El Menofiya and Cairo Governorate for prevalence of Aeromonase spp and examined bacteriologically and biochemically. Multiplex PCR was done to detect some virulence-associated genes in Aeromonas hydrophila isolates.

Results: The obtained results revealed that the incidence of Aeromonas species in examined minced meat, beef burger, kofta and sausage was (26.6\% (12), (15.5\% (7), 24.4\% (11) and (17.5\% (8) respectively. The most prevalent Aeromonase could be identified as A. hydrophilic, A. alcaligenes,A. caviae, A. sobria and A. veronii. 38 isolates of A. hydrophila were specific for $16 \mathrm{~S}$ rRNA gene of which 24 isolates were positive for aerolysin (aerA) and 21 of isolates were positive for haemolysin (ahhl), with incidence of $63.1 \%$ and $55.2 \%$, respectively.
\end{abstract}

Conclusion: It is necessary to give more attention to Aeromonads because they have the ability of toxins production, survival under low temperatures and growing in a wide spectrum of environments. So, hygienic measures should be adopted to control bacterial contamination.

\section{Introduction}

Meat products such as minced meat, beef burger, kofta and sausage are highly requested and considered more appealing to consumers than fresh meat due to their high nutritional value, fair price, good taste, easy to cook and also easy to serve. There is a concern about the importance of meat products to consumers, but they can be contaminated with several types of food borne microorganisms and because of the high humidity, the high percentage of nitrogenous compounds, the ample supply of minerals, some fermentable carbohydrates (glycogen) and a favorable $\mathrm{pH}$ for most microorganisms, they are regarded as the perfect culture medium for the growth of many microorganisms [1].

Aeromonas bacteria are considered major important pathogen and opportunistic pathogens in both immune competent and immune depressed persons [2]. In human Aeromonas spp. are the causes of both intestinal and extra-intestinal infections [3]. Five Aeromonas spp. represented as Aeromonas hydrophila, Aeromonas caviae, Aeromonas veronii, Aeromonas jandaei, and Aeromonas schubertii are commonly associated with human intestinal infections [2].

The pathogenesis of Aeromonas infections is multifactorial and not completely understood [2]. A wide range of virulence factors that are critical in the development of infection have been isolated in various Aeromonas organisms, such as enterotoxins, hemolysins, cytotoxins and aerolysinins [4].

These bacteria are capable of living well at $5^{\circ} \mathrm{C}$, and this can be an indication of their potential as a risk to public health. Aerolysin has been tested to be a virulence factor that is involved in the pathogenesis of A. Hydrophila [5] which may be essential at this temperature for raw food items that are stored in refrigeration and have a long validity period. Aeromonas species should also be monitored continuously in food products as they may be a source of food borne infection [6].

Considering all these hazards, the present study was planned to examine some meat products for the prevalence and characterization of Aeromonas spp.

\section{Material and Methods}

\section{Collection of samples}

A total of 180 samples of meat products represented by minced meat, beef burger, kofta and sausage ( 45 of each) collected in sterile plastic bags from different shops and supermarkets at El Menofiya 
and Cairo Governorate at different periods of time. All collected samples were examined bacteriologically as rapidly as possible for determination of their contamination with Aeromonas bacteria as well as detection of their virulence factors using PCR technique [7].

\section{Bacteriological examination}

Samples preparation [8]: Under complete aseptic conditions, 25 grams of the sample were weighed and transferred into a sterile homogenizer flask containing $225 \mathrm{ml}$ of sterile peptone water $(0.1 \%)$. The content of the flask was homogenized for 3 minutes at $14000 \mathrm{rpm}$ then allowed to stand for 5 minutes at room temperature. One $\mathrm{ml}$ from the homogenate was transferred into a separate tube containing $9 \mathrm{ml}$ of sterile peptone water $(0.1 \%)$ from which ten-fold serial dilutions were prepared. The prepared samples were subjected to the following examinations.

\section{Determination of Aeromonas count [9]}

Aeromonas agar medium is highly recommended for selective isolation of Aeromonas species. Take from original dilution 0.1 $\mathrm{ml}$ and streaked on Aeromonas agar base (Oxoid) supplemented with ampicillin and incubated for $24 \mathrm{~h}$ at $35^{\circ} \mathrm{C}$. Suspected colonies were dark green, opaque with darker center, diameter 0.5-1.5 mm. Presumptive identification of Aeromonas was made based on colony morphology and oxidase test (Oxoid). Identification of Aeromonas species by microscopical and biochemical identification [10].

\section{Polymerase Chain Reaction (PCR)}

Genomic DNA extraction: DNA Using Gene JET Genomic DNA Purification Kit. DNA amplified products "PCR master Mix" (Fermentis).

\section{Gel Elecrophoresis: Sambrook J, et al. [11].}

Primer sequences of A. hydrophila used for PCR system: Molecular identification of aerolysin (aerA) and haemolysin (ahh1) virulence genes of $A$. hydrophila was performed essentially by using the following primers.

\begin{tabular}{|c|c|c|c|c|}
\hline $\begin{array}{l}\text { Target } \\
\text { genes }\end{array}$ & Primers & Oligonucleotide sequence $\left(5^{\prime} \rightarrow 3^{\prime}\right)$ & $\begin{array}{l}\text { Product } \\
\text { size } \\
\text { (bp) }\end{array}$ & Reference \\
\hline \multirow[b]{2}{*}{ aerA } & $\begin{array}{l}\text { AH-aerA } \\
\text { (F) }\end{array}$ & 5' CAAGAACAAGTTCAAGTGGCCA 3' & & \multirow{4}{*}{$\begin{array}{l}\text { Stratev } \\
\text { D, et al. } \\
{[12]}\end{array}$} \\
\hline & $\begin{array}{l}\text { AH-aerA } \\
\text { (R) }\end{array}$ & 5' ACGAAGGTGTGGTTCCAGT 3' & 309 & \\
\hline \multirow[b]{2}{*}{ ahh1 } & $\begin{array}{l}\text { AHH1 } \\
\text { (F) }\end{array}$ & 5' GCCGAGCGCCCAGAAGGTGAGTT 3' & \multirow[b]{2}{*}{130} & \\
\hline & $\begin{array}{l}\text { AHH1 } \\
\text { (R) }\end{array}$ & 5' GAGCGGCTGGATGCGGTTGT 3' & & \\
\hline
\end{tabular}

\section{Results and Discussion}

Meat products such as minced meat, beef burger, kofta and sausage are highly demanded than fresh meat due to their high nutritive value, reasonable price, good taste, quick easily prepared and also easily serving but they can be contaminated by several types of food borne microorganisms from different sources during handling, preparation and Processing.

Aeromonas species recognized as potential food borne pathogens for more than 20 years. The bacterium can cause self-limiting diarrhea, mainly in children. Aeromonads are not resistant to food processing regimes and are readily killed by heat treatment [13].
Results given in table 1 revealed that incidence of Aeromonas species in the examined minced meat was (26.6\%) relatively higher incidence reported by Yucel N, et al. [14] who isolated Aeromonase with percentage of $40(67.7 \%)$ and Neyts K, et al. [15] isolated Aeromonase with percentage of $(70 \%)$ while in the examined beef burger was (15.5\%). Comparatively lower results obtained by Kingombe CIB, et al. [16] isolated Aeromonase by the percentage of (32.3\%) Rather MA, et al. [17] isolated Aeromonase by the percentage of (19.3\%) while in the examined kofta was $(24.4 \%)$ lower rate reported by Villari who isolated Aeromonas spp by the percentage of (14.4\%). The last of the examined sausage was (17.5\%) lower rate reported by Elmanama AA, et al. [18] who isolated Aeromonase by the percentage of (48.9\%) and agree with Fontes MC, et al. [19] who detected 84 isolates of Aeromonase spp. in 32 sample of sausage.

Results showed that the most contaminated product Sausages which considered as an ideal culture medium for growth of many microorganisms as Pseudomonas and Aeromonas resulting in their spoilage, economic losses, food borne infections in human and health risk [20].

Meat products may be contaminated with microorganisms from meat handlers, which carry of pathogenic microorganism during the processes of manufacturing, packing and marketing. Food borne pathogens are the leading causes of illness and death in developing countries costing billions of dollars in medical care, medical and social costs [21].

Results given in table 2 revealed that the incidence of identified aeromonase species in the examined samples of minced meat were $A$. hydrophila $13.3 \%$, A. alcaligenes $4.4 \%$, A. caviae $4.4 \%$, A. sobria $2.2 \%$ and $A$. Veronii $2.2 \%$ these results agree with Neyts K, et al. [15] who isolated A. hydrophila, A. sobria and A. caviae. Yucel N, et al. [14] who isolated (A. hydrophila, A. caviae and A. sobria) while in the examined samples of beef burger were $A$. hydrophila $8.8 \%$, A. alcaligenes $2.2 \%, A$. caviae $2.2 \%$ and $A$. sobria $2.2 \%$ these results lower agree with Manna SK, et al. [22] isolated Aeromonas hydrophila (43.2\%), Aeromonas caviae (12.2\%) and Aeromonas sobria (12.2\%) while in the examined kofta were A. hydrophila $15.5 \%$, A. alcaligenese $2.2 \%$, A. caviae $4.4 \%$ and $A$. sobria $2.2 \%$ these results agree with Stratev D, et al. $[23,12]$ who isolated Aeromonas hydrophila, Aeromonas caviae and Aeromonas sobria. The last one of the examined sausage was A. hydrophila $6.6 \%$, A. alcaligenes $4.4 \%$, A. caviae $2.2 \%$, A. sobria $2.2 \%$ and $A$. veronii $2.2 \%$. These results agree with Elmanama AA, et al. [18] who isolated for $A$. hydrophila with the incidence of (48.9\%) in food samples and agree with Osman K, et al. [24] who isolated. Aeromonas Hydrophila was isolated as the most prevalent species followed by Aeromonas caviae and Aeromonas sobria.

Results obtained in table 3 and figure 1 revealed that the incidence of virulence genes of $A$. hydrophila strains isolate from the examined samples of meat products. By using PCR were aerolysin gene (aerA) 63.1\%, haemolysin gene (ahhl) 55.2\% and aerolysin gene (aerA) with haemolysin gene (ahhl) 50\%, these results agree with Yucel N, et al. [14] found that A. hydrophila have virulence factors such as haemolysin, aerolysin, proteases, lipases, DNAses and disagree with Galindo CL, et al. [25] who detect the cytotoxic enterotoxin, Act gene in A. hydrophila. While Osman K, et al. [24] detected aerolysin toxin gene (aerA) in 3/17 isolates of A. hydrophila and Praveen PK, et al. [5] who detected that aerolysin is a virulence factor contributing to the pathogenesis of Aeromonas hydrophila infection. The current findings demonstrate that the combined use of PCR-based virulence marker detection, PCR-RFLP and PCR-ASA offers a rapid, sensitive, and 


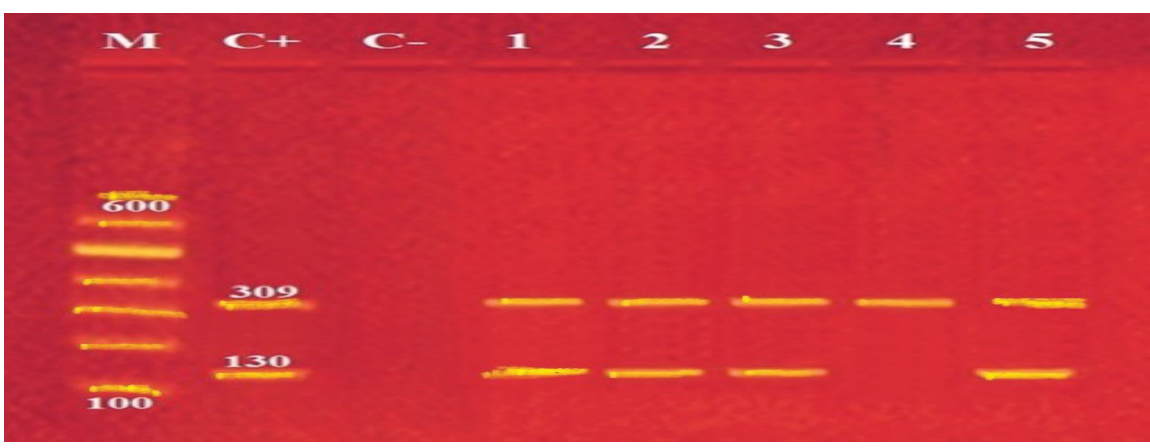

Figure 1: Agarose gel electrophoresis of multiplex PCR of aerA (309 bp) and ahhl (13 bp) genes for characterization of Aeromonas hydrophila. Lane M: 100 bp ladder as molecular size DNA marker.

Lane C: Control positive A. hydrophila foraerAand ahhlgenes.

Lane C: Control negative.

Lanes 1 \& 2 \& 3 \& 5: Positive A. hydrophila strains foraerA and ahhlgenes.

Lane 4: Positive A. hydrophila strain forahhlgenes.

Table 1: Incidence of Aeromonas species in the examined samples of meat products $(n=45)$.

\begin{tabular}{|l|c|c|c|}
\hline Meat products & No. of ex. samples & No & $\%$ \\
\hline Minced meat & 45 & 12 & 26.6 \\
\hline Beef burger & 45 & 7 & 15.5 \\
\hline Kofta & 45 & 11 & 24.4 \\
\hline Sausage & 45 & 8 & 17.7 \\
\hline Total & 180 & 38 & 21.1 \\
\hline
\end{tabular}

Table 2: Incidence of identified Aeromonas species in the examined samples of meat products $(n=45)$.

\begin{tabular}{|c|c|c|c|c|c|c|c|c|}
\hline \multirow{2}{*}{$\begin{array}{c}\text { Meat } \\
\text { products } \\
\text { Areomonas } \\
\text { strains }\end{array}$} & \multicolumn{2}{|c|}{ Minced Meat } & \multicolumn{2}{|c|}{ Beef Burger } & \multicolumn{2}{|c|}{ Beef Kofta } & \multicolumn{2}{|c|}{$\begin{array}{c}\text { Beef } \\
\text { Sausage }\end{array}$} \\
\hline & No. & $\%$ & No. & $\%$ & No. & $\%$ & No. & $\%$ \\
\hline A. hydrophila & 6 & 13.3 & 4 & 8.8 & 7 & 15.5 & 3 & 6.6 \\
\hline A. alcaligenes & 2 & 4.4 & 1 & 2.2 & 1 & 2.2 & 2 & 4.4 \\
\hline A. caviae & 2 & 4.4 & 1 & 2.2 & 2 & 4.4 & 1 & 2.2 \\
\hline A. sobria & 1 & 2.2 & 1 & 2.2 & 1 & 2.2 & 1 & 2.2 \\
\hline A. veronii & 1 & 2.2 & 0 & 0 & 0 & 0 & 1 & 2.2 \\
\hline Total & 12 & 26.6 & 7 & 15.5 & 11 & 24.4 & 8 & 17.7 \\
\hline
\end{tabular}

Table 3: Occurrence of virulence genes of Aeromonas hydrophila isolated from the examined samples of meat products $(n=38)$.

\begin{tabular}{|l|c|c|c|}
\hline \multirow{2}{*}{ Gene type } & \multirow{2}{*}{ No. of tested strains } & \multicolumn{2}{c|}{ Positive strains } \\
\cline { 2 - 4 } & & No & \% \\
\hline aerA & 38 & 24 & 63.1 \\
\hline Ahhl & 38 & 21 & 55.2 \\
\hline aerA and Ahhl & 38 & 19 & 50 \\
\hline
\end{tabular}

specific system to assess the presence and prevalence of Aeromonas spp. harboring virulence markers in food samples [16].

\section{Conclusion}

The results achieved in the current study indicated the high contamination in minced meat and kofta and lowest contamination in sausage and burger by Aeromonas spp which may play a major role as a source of the transmission of Aeromonads from animals to human. A way from consumption of contaminated foods, another possible food borne infection can occur due to ingestion of food containing preformed exotoxins. Isolates of $A$. hydrophila have virulence-associated genes. It is important to give more attention to Aeromonads because they are able to produce toxin, grow under low temperatures and broad spectrum of environments so hygienic measures should be adopted in processing meat products to control microbial contamination. The results of this study emphasize the need for effective hygienic and sanitation procedures in meat products production to reduce the risks of contamination with Aermonas bacteria.

\section{References}

1. Al-Mutairi MF (2011) The Incidence of Enterobacteriaceae Causing Food Poisoning in Some Meat Products. Adv J Food Sci Technol 3: 116-121.

2. Janda JM, Abbott SL (2010) The Genus Aeromonas: Taxonomy, Pathogenicity, and Infection. Clin Microbiol Rev 23: 35-73.

3. Khajanchi BK, Fadl AA, Borchardt MA, Berg RL, Horneman AJ, et al. (2010) Distribution of virulence factors and molecular fingerprinting of isolates from water and clinical samples: suggestive evidence of water-to-human transmission. Appl Environ Microbiol 76: 23132325.

4. Yucel N, Erdogan S (2010) Virulence Properties and Characterization of Aeromonads Isolated from Foods of Animal Origin and Environmental Sources. J Food Prot 73: 855-860.

5. Praveen PK, Debnath C, Shekhar S, Dalai N, Ganguly S (2016) Incidence of Aeromonas spp. infection in fish and chicken meat and its related public health hazards: A review. Vet World 9: 6-11.

6. Soltan DMM, Yazdi MKS, Avadisians S (2012) Study of prevalence and antibiotic resistance in Aeromonas species isolated from minced meat and chicken samples in Iran. Afr J Microbiol Res 6: 460-464. 
7. Splittstoesser DF (1992) Compendium of Methods for the Microbiological Examination of Foods ( $3^{\text {rd }}$ ed) American Public Health Association, Washington, USA 1219.

8. FDA (2002) Enumeration of coliform bacteria and identification of $E$. coli. In: Bacteriological Analytical Manual. $8^{\text {th }}$ Edition, USA.

9. ISO (International Standards Organization) (2004) Microbiology of food and animal feeding stuffs. Horizontal method for detection and enumeration of Enterobacteriaceae, Part 2: colony count method. International Standards Organization, Geneva.

10. MacFaddin JF (2000) Biochemical tests for identification medical bacteria. Lippincott Williams \& Wilkins, Baltimore, USA 912.

11. Sambrook J, Fritsch EF, Maniatis T(1989) Molecular cloning: Laboratory Manual, $2^{\text {nd }}$ Edition, New York, USA 676.

12. Stratev D, Vashin I, Rusev V (2012) Prevalence and survival of Aeromonas spp. in foods ? A review. Revue Med Vet 163: 486-494.

13. Isonhood JH, Drake M (2002) Aeromonas species in foods. J Food Prot 65: 575-82.

14. Yucel N, Çitak S (2003) The occurrence, hemolytic activity and antibiotic susceptibility of motile Aeromonas spp. isolated from meat and milk samples in Turkey. J Food Saf 23: 189-200.

15. Neyts K, Huys G, Uyttendaele M, Swings J, Debevere J (2001) Incidence and identification of mesophilic Aeromonas spp. from retail foods. Lett Appl Microbiol 31: 359-363.

16. Kingombe CIB, Huys G, Howald D, Luthi E, Swings J, et al. (2004) The usefulness of molecular techniques to assess the presence of Aeromonas spp harboring virulence markers in foods. Int J Food Microbiol 94: 113-121.

17. Rather MA, Willayat MM, Wani SA, Munshi ZH, Hussain SA (2014) A multiplex PCR for detection of enterotoxin genes in Aeromonas species isolated from foods of animal origin and human diarrhoeal samples. J Appl Microbiol 117: 1721-1729.
18. Elmanama AA, Ferwana N (2011) Yersinia enterocolitica and Aeromonas hydrophila in clinical, food and environmental samples in gaza strip. J Al Azhar Univ Gaza 13: 69-82.

19. Fontes MC, Saavedra MJ, Martins C, Martínez-Murcia AJ (2011) Phylogenetic identification of Aeromonas from pigs slaughtered for consumption in slaughterhouses at the North of Portugal. Int J Food Microbiol 146: 118-122.

20. Ercolini D, Russo F, Nasi A, Ferranti P, Villani F (2009) Mesophilic and psychrotrophic bacteria from meat and their spoilage potential in vitro and in beef. Appl Environ Microbiol 75: 1990-2001.

21. Bhunia AK, Smith JL, Fratamico PM (2005) Foodborne Pathogens in Microbiology and Molecular Biology, Caister Academic Press, UK: 453.

22. Manna SK, Maurye P, Dutta C, Samanta G (2013) Occurrence and Virulence Characteristics of Aeromonas Species in Meat, Milk and Fish in India. J Food Saf 33: 461-469.

23. Stratev D, Odeyemi OA (2015) Antimicrobial resistance of Aeromonas hydrophila isolated from different food sources: A minireview. J Infect Public Health 9: 535-544.

24. Osman K, Aly M, Kheader A, Mabrok K (2012) Molecular detection of the Aeromonas virulence aerolysin gene in retail meats from different animal sources in Egypt. World J Microbiol Biotechnol 28: 1863-1870.

25. Galindo CL, Chopra AK (2007) Aeromonas and Plesiomonas species. In: Food Microbiology: Fundamentals and Frontiers $\left(3^{\text {rd }}\right.$ Ed) American Society of Microbiology USA: 381-400. 